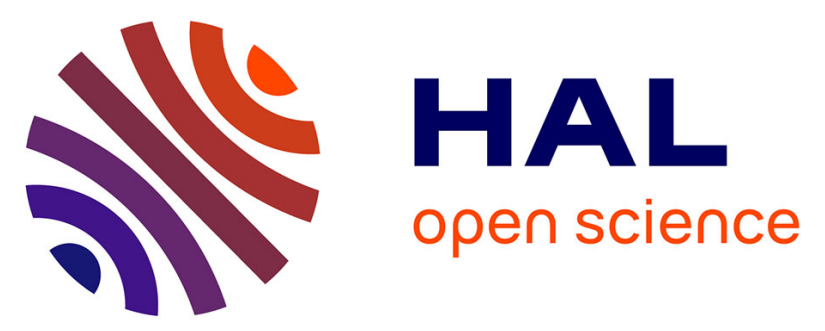

\title{
Synthesis and evaluation as biodegradable herbicides of halogenated analogs of L-meta-tyrosine
}

Julie Movellan, Francoise Rocher, Zohra Chikh, Cécile Marivingt-Mounir, Jean-Louis Bonnemain, Jean-François Chollet

\section{- To cite this version:}

Julie Movellan, Francoise Rocher, Zohra Chikh, Cécile Marivingt-Mounir, Jean-Louis Bonnemain, et al. Synthesis and evaluation as biodegradable herbicides of halogenated analogs of L-meta-tyrosine. Environmental Science and Pollution Research, 2014, 21 (7), pp.4861-4870. 10.1007/s11356-012-13025. hal-02895216

\section{HAL Id: hal-02895216 https://hal.science/hal-02895216}

Submitted on 9 Jul 2020

HAL is a multi-disciplinary open access archive for the deposit and dissemination of scientific research documents, whether they are published or not. The documents may come from teaching and research institutions in France or abroad, or from public or private research centers.
L'archive ouverte pluridisciplinaire HAL, est destinée au dépôt et à la diffusion de documents scientifiques de niveau recherche, publiés ou non, émanant des établissements d'enseignement et de recherche français ou étrangers, des laboratoires publics ou privés. 


\section{Synthesis and Evaluation as Biodegradable Herbicides of Halogenated Analogues of L-meta- Tyrosine}

Julie Movellan ${ }^{\mathrm{a}}$, Françoise Rocher ${ }^{\mathrm{a}}$, Zohra Chikh ${ }^{\mathrm{a}}$, Cécile Marivingt-Mounir ${ }^{\mathrm{a}}$, Jean-Louis Bonnemain $^{\mathrm{b}}$ and Jean-François Chollet ${ }^{\mathrm{a}, *}$

${ }^{a}$ Institut de Chimie des Milieux et des Matériaux de Poitiers, Unité Mixte de Recherche CNRS 7285, Université de Poitiers, 40 avenue du Recteur Pineau, F-86022 Poitiers cedex, France

${ }^{b}$ Laboratoire Écologie et Biologie des Interactions, Unité Mixte de Recherche CNRS 7267, Université de Poitiers, 40 avenue du Recteur Pineau, F-86022 Poitiers cedex, France

* Corresponding author: Tel. fax: +33 549453965

E-mail address: jean.franc.chollet@univ-poitiers.fr

This work was presented at the $42^{\text {th }}$ Congress of the "Groupe Français des Pesticides" which was held in Poitiers from 30 May to 1 June 2012 


\begin{abstract}
L-meta-tyrosine is a herbicidal non protein amino acid isolated some years ago from fine fescue grasses and characterized by its almost immediate microbial degradation in soil (half life less than 24 hours). Nine mono- or dihalogenated analogs of this allelochemical have been obtained through a seven-step stereoselective synthesis from commercial halogenated phenols. Bioassays showed a large range of biological responses, from a growth root inhibition of lettuce seedling similar to that noted with $m$-tyrosine [2-amino-3-(2chloro-5-hydroxyphenyl)propanoic acid or compound $\mathbf{8 b}$ ] to an increase of the primary root growth concomitant with a delay of secondary root initiation [2-amino-3-[2-fluoro-5-hydroxy-3-(trifluoromethyl)phenyl]propanoic acid or compound $\mathbf{8 h}$ ]. Compound $\mathbf{8 b}$ was slightly less degraded than $m$-tyrosine in the non-sterilized nutritive solution used for lettuce development while the concentration of compound $\mathbf{8 h}$ remained unchanged for at least two weeks. These data indicate that it is possible to manipulate both biological properties and degradation of $m$ tyrosine by halogen addition.
\end{abstract}

Keywords Allelochemicals; Allelopathy; m-Tyrosine; Halogenated Analogues of L-metatyrosine; Herbicide; Sustainable agriculture 


\section{Introduction}

Protection of crops against pests probably arose at the same time as agriculture itself. Modern crop protection developed quickly after the Second World War with the advent of organic chemistry and numerous active ingredients became available in various domains: organophosphate and organochlorine insecticides, dithiocarbamate fungicides or auxinic herbicides also called phytohormones. These compounds were widely used to meet the high demand for food after the war without adequate assessment of the risks that could result from the use of some molecules (Zadoks 1991). However, after many years, adverse effects on health or environment were often highlighted. Herbicides of the triazine family are leached and found in groundwater (Felding 1992b, a, Hall et al. 1991) while organochlorine insecticides may accumulate in the environment or in lipophilic parts of some organisms (Caro 1969, Mueller et al. 2008, Ntow et al. 2008, Smith \&Gangolli 2002). Thus, intensive agriculture, as practiced for several decades in developed countries, is changing and in particular, the part concerning the protection of cultivated plants (Rabbinge \&vanOijen 1997). Many phytopharmaceutical compounds were withdrawn from the market after adverse effects were demonstrated (Karabelas et al. 2009). The arsenal of agrochemical products is restricted and no major mode of herbicide action has been introduced to the market place for about two decades (Duke 2012). Therefore new strategies must emerge to meet the specific requirements for crop protection in a context of sustainable agriculture (Clark 2012, Dayan et al. 2012, Duke 2012, Epstein \&Bassein 2003, Gosme et al. 2010, Jacobsen 1997, Tesio \&Ferrero 2010, van Lenteren 2000).

Thus, in order to identify new molecules able to control weed growth, allelopathy may be a promising way and in particular, to develop new synthetic herbicide families (Bais et al. 2006, Birkett et al. 2001, Duke \&Abbas 1995, Duke et al. 2005, Duke \&Lydon 1993, Farooq et al. 2011, John et al. 2010, Macias 1995, Niemeyer 2009, Petroski \&Stanley 2009, Vyvyan 2002). The definition of allelopathy has evolved over the years (Duke 2010, Molisch 1937, Rice 1984, Whittaker \&Feeny 1971) and currently, allelopathy is defined by the International Allelopathy Society as any process involving secondary metabolites produced by plants, algae, bacteria and fungi that influences the growth and development of agriculture and biological systems (Chou 2006). More restrictively, allelochemicals are substances that are produced by one plant. Phenolics compounds are an important and common family of plant allelochemicals in the ecosystem (Li et al. 2010, Wu et al. 2001). Recently, Bertin et al have isolated L-meta-tyrosine, a non protein amino acid exuded by the roots of fine fescue grasses, 
especially Festuca rubra spp commutata (Bertin \&Weston 2002, Bertin et al. 2007, Weston et al. 2006). This compound which is synthesized by hydroxylation of phenylalanine in F. rubra (Huang et al. 2012) exhibits herbicidal properties for a wide range of plant species (Bertin et al. 2007). More specifically $m$-tyrosine is a root growth inhibitor, contrary to its position isomers, tyrosine and ortho-tyrosine (Bertin et al. 2007). The mechanisms of $m$-tyrosine herbicidal activity are not known (Bertin et al. 2007). Furthermore, the concentrations required for significant root growth inhibition in the same plant species may vary considerably when filter paper bioassays are used (Bertin et al. 2007, Kaur et al. 2009) and may be higher than what would normally be found in Festuca rubra spp commutata rhizosphere (Kaur et al. 2009). This latter data and the rapid microbially loss of $m$-tyrosine in soil have raised a recent debate about the actual role of $m$-tyrosine in allelopathy (Bertin et al. 2009, Duke 2010, Kaur et al. 2009).

Here we report the synthesis in a stereo specific manner of nine mono- or polyhalogenated analogues of L-meta-tyrosine (Table 1). Using two bioassays methods, the phytotoxic activity of these compounds was then compared to that of $m$-tyrosine. Our data 1-support that $\mathrm{m}$ tyrosine is an efficient allelopathic compound, 2-demonstrate for the first time that manipulation of both biological properties and degradation of $\mathrm{m}$-tyrosine by halogen addition is possible and 3-point out two derivatives that may be used as tools to elucidate the mechanisms of the biological activity of m-tyrosine.

\section{Material and methods}

\section{Synthesis}

${ }^{1} \mathrm{H}$ and ${ }^{13} \mathrm{C}$ FT-NMR spectra were measured with a Varian Model XL 400-MHZ spectrometer. Chemical shifts are reported as $\delta$ in units of parts per million (ppm) relative to chloroform $\left({ }^{1} \mathrm{H} 7.26 \mathrm{ppm},{ }^{13} \mathrm{C} 77 \mathrm{ppm}\right)$ or water $\left({ }^{1} \mathrm{H} 4.79 \mathrm{ppm}\right)$. Multiplicities are reported as follows: s (singlet), d (doublet), $\mathrm{t}$ (triplet), qd (quadruplet), dd (doublet of doublets), $\mathrm{m}$ (multiplet). Coupling constants are reported as a $\mathrm{J}$ value in Hertz $(\mathrm{Hz})$. The number of protons (n) for a given resonance is indicated as $\mathrm{nH}$, and is based on spectral integration values. Melting points were determined on an Electrothermal IA9200 apparatus and are uncorrected. Mass spectra were recorded using a Waters 3100 spectrometer in electro spray mode.

\section{In vitro bioassays}

In a first approach, biological effect of each halogenated compound was assessed in comparison to $m$-tyrosine using filter paper bioassays with lettuce (Bertin et al. 2007). Ten 
non-sterilized seeds (Lactuca sativa Var. Blonde de Paris) were placed in $9 \mathrm{~cm}$ Petri dishes on a filter paper impregnated with $1.5 \mathrm{~mL}$ of aqueous solutions of the tested compound at 0,40 , $80,160,320$ or $640 \mu \mathrm{M}$ concentrations. To avoid evaporation, Petri dishes were sealed with Parafilm $^{\circledR}$. Two replicates of each assay were maintained under dim daylight conditions in a controlled environment $\left(21 \pm 0.5^{\circ} \mathrm{C}\right.$, HR $\left.90 \% \pm 5 \%\right)$. Radicle length was measured 4 days later.

The biological activities of $m$-tyrosine, $\mathbf{8 b}$ and $\mathbf{8 h}$ were also studied under non-sterilized hydroponic conditions. Shortened Pasteur pipettes were immersed in $15 \mathrm{~mL}$ centrifuge tubes filled with a nutrient solution composed of $2 \mathrm{mmol}^{-1}$ of $\mathrm{KNO}_{3}, 1 \mathrm{mmol} . \mathrm{l}^{-1}$ of $\mathrm{KH}_{2} \mathrm{PO}_{4}, 1$ mmol. $1^{-1}$ of $\mathrm{Ca}\left(\mathrm{NO}_{3}\right)_{2}, 1 \mathrm{mmol} .1^{-1}$ of $\mathrm{MgSO}_{4} \cdot 7 \mathrm{H}_{2} \mathrm{O}, 0.3 \mu$ mol. $1^{-1}$ (molybdenum equivalent) of $\left(\mathrm{NH}_{4}\right)_{6} \mathrm{Mo}_{7} \mathrm{O}_{24}, 1 \mu \mathrm{mol} .1^{-1}$ of $\mathrm{H}_{3} \mathrm{BO}_{3}, 0.09 \mu \mathrm{mol}^{-1}{ }^{-1}$ of $\mathrm{MnSO}_{4}, \mathrm{H}_{2} \mathrm{O}, 0.12 \mu \mathrm{mol}^{-1}{ }^{-1}$ of $\mathrm{NH}_{4} \mathrm{NO}_{3}$, $0.035 \mu \mathrm{mol}^{-1}$ of $\mathrm{ZnSO}_{4} .7 \mathrm{H}_{2} \mathrm{O}$ and $18 \mu \mathrm{mol}^{-1}$ of iron-EDDHA chelate $6 \% \mathrm{Fe}$. In these experiments, germination of lettuce seeds (Lactuca sativa Var. Blonde de Paris) occurs on an agar layer (4 mm high) at the top of each Pasteur pipette. Under these conditions, the radicle had to cross this layer to reach the nutritive solution. Unless stated otherwise, plants were grown at $24 \pm 0.5^{\circ} \mathrm{C}$ and $60 \pm 5 \% \mathrm{RH}$ during the photoperiod $(14 \mathrm{~h}, 250 \mu \mathrm{mol}$ photons.m $\left.{ }^{-2} \cdot \mathrm{s}^{-1}\right)$.

\section{Results and discussion}

\section{Synthesis of halogenated analogues of $\boldsymbol{m}$-tyrosine}

Several methods of synthesis for halogenated meta-tyrosine or tyrosine were previously proposed (Bovonsombat et al. 2008, Drain \&Howes 1967, Kirk et al. 1986, Konkel et al. 2002). Fluorinated analogues and particularly 6-fluoro-meta-tyrosine (Table 1, 8d) was synthesized to use it as a tracer for medical imaging (Konkel et al. 2002, VanBrocklin et al. 2004, Vasdev et al. 2001). Halogenated $m$-tyrosine derivatives were found to lower the blood pressure of mammals (Drain \&Howes 1967). Finally, we chose the synthesis in seven steps proposed by Konkel et al (Kirk et al. 1986, Konkel et al. 2002) and among the nine products that were synthesized (Table 1), six were new (compounds 8a, 8b, 8e, 8f, 8h and 8i). The first six steps were performed with good to very good yields, whose median is between $65 \%$ (steps 2 and 4) and 95\% (step 6). Only the last step (deprotection of the alpha-amino acid function) deserves to be optimized for some products, the yields ranging from $5 \%(\mathbf{8 g})$ to $64 \%$ (8c) (median 42\%). An interesting aspect of the proposed method is also the possibility of using crude products obtained at the end of reaction for the next step without further purifications. 


\section{Protection of the hydroxyl group of the phenolic derivatives (Fig. 1, 2a-i)}

To a solution of 2-chlorophenol (1a, $6.43 \mathrm{~g}, 50 \mathrm{mmol})$ in dimethylformamide $(25 \mathrm{~mL})$, were added imidazole (3.75 g, $55 \mathrm{mmol}$ ) and ter-butyldimethylsilyl chloride (TBDMSCl, $8.29 \mathrm{~g}, 55$ mmol). The mildly exothermic reaction was placed in an iced-bath. After the solution was stirred overnight under nitrogen atmosphere, water $(125 \mathrm{~mL})$ was added and the mixture was extracted with pentane $(3 \times 50 \mathrm{~mL})$. The organic layer was washed successively with water $(50 \mathrm{~mL}), 10 \%$ sodium carbonate aqueous solution $(3 \times 50 \mathrm{~mL})$, water $(3 \times 50 \mathrm{~mL})$ and dried over anhydrous magnesium sulphate. Removal of solvent under reduced pressure gave 2a $(9.04 \mathrm{~g}, 37 \mathrm{mmol})$ which was used without further purification. The products $\mathbf{2 b}$-i were obtained following the same procedure. Yields and ${ }^{1} \mathrm{H}$ NMR spectra for compounds $\mathbf{2 a - i}$ are given in the online resource 1 in the ESM.

\section{Preparation of aldehydes (Fig. 1, 3a-i)}

To a solution of tert-butyl(2-chlorophenoxy)dimethylsilane (2a, $8.9 \mathrm{~g}, 36.7 \mathrm{mmol})$ in dry THF $(25 \mathrm{~mL})$ stirred under argon atmosphere and cooled to $-78^{\circ} \mathrm{C}$, was added dropwise a solution of sec-butyllithium in hexane (1.4 M, $29 \mathrm{~mL}, 40 \mathrm{mmol})$. After stirring for 1 hour, an excess $(3 \mathrm{~mL}, 40 \mathrm{mmol})$ of distillated DMF was added dropwise at $-78{ }^{\circ} \mathrm{C}$. After $30 \mathrm{~min}$, tetrabutylammonium fluoride (TBAF, $1 \mathrm{M}$ in THF, $44.5 \mathrm{~mL}, 44.5 \mathrm{mmol}$ ) was added dropwise at the same temperature. After 1.5 hour, the reaction was allowed to warm to room temperature, and water $(50 \mathrm{~mL})$ was added. After removal of most of the THF under reduced pressure, aqueous sodium hydroxide solution $(1 \mathrm{~N}, 25 \mathrm{~mL})$ was added and the basic solution was washed with diethyl ether $(3 \times 50 \mathrm{~mL})$. The organic layer was washed 3 times with aqueous sodium hydroxide solution $(1 \mathrm{~N}, 25 \mathrm{~mL})$. The combined aqueous layers were acidified with hydrochloric acid solution $(3 \mathrm{M})$, and the product was extracted with diethyl ether $(4 \times 50 \mathrm{~mL})$. After drying over anhydrous magnesium sulphate, removal of solvent under reduced pressure gave 3a $(2.25 \mathrm{~g}, 14.4 \mathrm{mmol})$ that was used without further purification. The products $\mathbf{3 b}$-i were obtained following the same procedure. Yields and ${ }^{1} \mathrm{H}$ NMR spectra for compounds 3a-i are given in the online resource 2 in the ESM.

\section{Benzylation of the hydroxyl group (Fig. 1, 4a-i)}

To a solution of 2-chloro-3-hydroxybenzaldehyde (3a, $2.25 \mathrm{~g}, 16 \mathrm{mmol})$ in DMF (20 mL), potassium carbonate was added $(2.30 \mathrm{~g}, 23 \mathrm{mmol})$. After 5 minutes of stirring, benzyl bromide $(2.15 \mathrm{~mL}, 18 \mathrm{mmol})$ was added dropwise. The reaction mixture was stirred at room temperature for 20 hours. Diethyl ether $(30 \mathrm{~mL})$ was added and the mixture was washed with 
water $(3 \times 20 \mathrm{~mL})$. The organic layer was dried over anhydrous magnesium sulphate and the removal of solvent under reduced pressure gave $4 \mathbf{a}(3.33 \mathrm{~g}, 13.5 \mathrm{mmol})$ that was used without further purification. The products $\mathbf{4 b - i}$ were obtained following the same procedure. Yields and ${ }^{1} \mathrm{H}$ NMR spectra for compounds $\mathbf{4 a - i}$ are given in the online resource 3 in the ESM.

\section{Preparation of azalactones (Fig. 1, 5a-i)}

To a solution of 3-(benzyloxy)-2-chlorobenzaldehyde (4a, $3.2 \mathrm{~g}, 13 \mathrm{mmol}$ ) in acetic anhydride $(25 \mathrm{~mL})$ were added sodium acetate $(1.23 \mathrm{~g}, 15 \mathrm{mmol})$ and hippuric acid $(2.69 \mathrm{~g}$, $15 \mathrm{mmol}$ ). The reaction mixture was stirred at $80{ }^{\circ} \mathrm{C}$ for 2 hours and cooled at room temperature and with an iced-bath. Cold ethanol $(30 \mathrm{~mL})$ was added and after $15 \mathrm{~min}$, iced water $(15 \mathrm{~mL})$ was added. The orange precipitate was collected by filtration on Büchner and dried under vacuum to give 5a $(3.32 \mathrm{~g}, 8.53 \mathrm{mmol})$ that was used without further purification. The products $\mathbf{5 b}$-i were obtained following the same procedure. Yields and ${ }^{1} \mathrm{H}$ NMR spectra for compounds 5a-i are given in the online resource 4 in the ESM.

\section{Ring opening of the azalactones (Fig. 1, 6a-i)}

(Z)-4-(3-(benzyloxy)-2-chlorobenzylidene)-2-phenyloxazol-5(4H)-one (5a, 3.23 g, 8.3 mmol) and sodium acetate $(730 \mathrm{mg}, 8.9 \mathrm{mmol})$ in $\mathrm{MeOH}(400 \mathrm{~mL})$ were stirred at room temperature. After 1 hour, the solvent was removed under reduced pressure. The residue was dissolved in ethylacetate $(200 \mathrm{~mL})$ and washed with water $(3 \times 50 \mathrm{~mL})$. The organic phase was dried over anhydrous magnesium sulphate and the solvent was evaporated to give 6a $(3.30 \mathrm{~g}, 7.82$ mmol) that was used without further purification. The products $\mathbf{6 b}-\mathbf{i}$ were obtained following the same procedure. Yields and ${ }^{1} \mathrm{H}$ NMR spectra for compounds $\mathbf{6 a - i}$ are given in the online resource 5 in the ESM.

\section{Debenzylation and double bond saturation (Fig. 1, 7a-i)}

A solution of (E)-methyl-2-benzamido-3-(3-(benzyloxy)-2-chlorophenyl) acrylate (6a, $1.0 \mathrm{~g}$, $2.37 \mathrm{mmol})$ in $\mathrm{MeOH}(100 \mathrm{~mL})$ was hydrogenated over $10 \% \mathrm{Pd} / \mathrm{C}(205 \mathrm{mg})$ at $40 \mathrm{psi}$ for 20 h. The palladium was then filtered on celite and the methanol was evaporated to give $7 \mathbf{a}(0.79$ g, $2.37 \mathrm{mmol}$ ) which was used without further purification. The products $7 \mathbf{b}-\mathbf{e}$ and $\mathbf{7 g}$-i were obtained following the same procedure. 7f was obtained by hydrogenation at $60{ }^{\circ} \mathrm{C}$ under 80 psi during $20 \mathrm{~h}$. Yields and ${ }^{1} \mathrm{H}$ NMR spectra for compounds $\mathbf{7 a - i}$ are given in the online resource 6 in the ESM. 
Deprotection of the alpha-amino acid function to obtain L-m-tyrosine analogues (Table 1, Fig. 1, 8a-i)

A solution of methyl 2-benzamido-3-(2-chloro-3-hydroxyphenyl) propanoate (7a, $2.89 \mathrm{~g}$, $8.66 \mathrm{mmol})$ in hydrochloric acid $(3 \mathrm{M}, 125 \mathrm{~mL}$ ) was refluxed for $24 \mathrm{~h}$. The solution was concentrated to dryness and the residue was dissolved in water $(60 \mathrm{~mL})$ and washed with diethyl ether $(3 \times 20 \mathrm{~mL})$. The aqueous phase was then filtrated and neutralized to $\mathrm{pH} 6$ with an aqueous solution of sodium hydroxide $1 \mathrm{M}$. The water was evaporated until the formation of a precipitate. The precipitate was filtrated and product was dried under reduced pressure to give $8 \mathbf{a}(741 \mathrm{mg}, 3.43 \mathrm{mmol})$. The products $\mathbf{8 b}$-i were obtained following the same procedure. 8a, 2-amino-3-(2-chloro-3-hydroxyphenyl)propanoic acid, yield: 40\%; brown solid; ${ }^{1} \mathrm{H}$ NMR $\delta$ (ppm): $3.27-3.56$ (ABX system, $J_{A B}=14 \mathrm{~Hz}, J_{A X}=9 \mathrm{~Hz}, J_{B X}=5.2 \mathrm{~Hz}, 2 \mathrm{H}, \mathrm{CH}_{2}$ ), 4.44 (m, 1H, CH), 6.97 (d, $\left.{ }^{3} J=7.5 \mathrm{~Hz}, 1 \mathrm{H}, \mathrm{ArH}\right), 7.04\left(\mathrm{~d},{ }^{3} J=8.1 \mathrm{~Hz}, 1 \mathrm{H}, \mathrm{ArH}\right), 7.33$ (t, ${ }^{3} J=7.7$ $\mathrm{Hz}, 1 \mathrm{H}, \mathrm{ArH}) ;{ }^{13} \mathrm{C} \mathrm{NMR} \delta(\mathrm{ppm}):\left(\mathrm{D}_{2} \mathrm{O} / \mathrm{DCl}\right): 34.72\left(\mathrm{CH}_{2}\right), 54.5(\mathrm{CH}), 116.1\left(\mathrm{Ar}_{\mathrm{CH}}\right), 122.9$ (C-Cl), $127.9\left(2 \mathrm{Ar}_{\mathrm{CH}}\right), 134.5\left(\mathrm{Ar}_{\mathrm{Cq}}\right), 173.7(\mathrm{C}-\mathrm{OH}), 185.8(\mathrm{COOH})$; Calculated $[\mathrm{M}]^{+}$ $\left(\mathrm{C}_{9} \mathrm{H}_{10} \mathrm{ClNO}_{3}\right) m / z=215.03$. Found: ESI+: $[\mathrm{M}+\mathrm{H}]^{+} \mathrm{m} / z=216.08$

8b, 2-amino-3-(2-chloro-5-hydroxyphenyl)propanoic acid; yield: 16\%; grey solid; ${ }^{1} \mathrm{H}$ NMR $\left(D_{2} \mathrm{O} / \mathrm{DCl}\right) \delta(\mathrm{ppm}): 3.11\left(\mathrm{~m}, 1 \mathrm{H}, \mathrm{CH}_{2}\right), 3.33(\mathrm{ddd}, J=19.7 \mathrm{~Hz}, J=14.7 \mathrm{~Hz}, J=5.6 \mathrm{~Hz}, 1 \mathrm{H}$, $\mathrm{CH}_{2}$ ), 4.04-4.06 (m, 1H, CH), 6.85-6.87 (m, 2H, ArH), 7.32 (dd, $J=17.6 \mathrm{~Hz}, J=8.3 \mathrm{~Hz}, 1 \mathrm{H}$, $\mathrm{ArH}) ;{ }^{13} \mathrm{C} \mathrm{NMR}\left(\mathrm{D}_{2} \mathrm{O}\right) \delta(\mathrm{ppm}): 33.6\left(\mathrm{CH}_{2}\right), 53.7(\mathrm{CH}), 114.6\left(\mathrm{Ar}_{\mathrm{CH}}\right), 116.1\left(\mathrm{Ar}_{\mathrm{CH}}\right), 121.5$ $\left(\mathrm{Ar}_{\mathrm{CH}}\right), 130.5\left(\mathrm{Ar}_{\mathrm{Cq}}\right), 150.2(\mathrm{C}-\mathrm{OH}), 158.5(\mathrm{C}-\mathrm{Cl}), 170.2(\mathrm{COOH}) ;$ Calculated $[\mathrm{M}]^{+}$ $\left(\mathrm{C}_{9} \mathrm{H}_{10} \mathrm{ClNO}_{3}\right) m / z=215.03$. Found: ESI+: $[\mathrm{M}+\mathrm{H}]^{+} m / z=216.08$

8c, 2-amino-3-(2-fluoro-3-hydroxyphenyl)propanoic acid; yield: 64\%; pink crystals; ${ }^{1} \mathrm{H}$ NMR $\left(D_{2} O\right) \delta(p p m): 3.15-3.36$ (ABX syst., $J_{\mathrm{AB}}=14.4 \mathrm{~Hz}, J_{\mathrm{AX}}=7.6 \mathrm{~Hz}, J_{\mathrm{BX}}=4.8 \mathrm{~Hz}, 2 \mathrm{H}, \mathrm{CH}_{2}$ ), $4.11\left(\mathrm{t}, 1 \mathrm{H},{ }^{3} J=5.6 \mathrm{~Hz}, \mathrm{CH}\right), 6.84\left(\mathrm{t}, 1 \mathrm{H},{ }^{3} J=6.2 \mathrm{~Hz}, 1 \mathrm{H}, \mathrm{ArH}\right), 6,98\left(\mathrm{dt}, 1 \mathrm{H},{ }^{4} J=1.7 \mathrm{~Hz},{ }^{3} J\right.$ $=8.3 \mathrm{~Hz}, 1 \mathrm{H}, \mathrm{ArH}), 7.05\left(\mathrm{t}, 1 \mathrm{H},{ }^{3} J=7.8 \mathrm{~Hz}, 1 \mathrm{H}, \mathrm{ArH}\right) ;{ }^{13} \mathrm{C} \mathrm{NMR}\left(\mathrm{D}_{2} \mathrm{O}\right) \delta(p p m): 33.1\left(\mathrm{CH}_{2}\right)$, $57.9(\mathrm{CH}), 120.1\left(\mathrm{Ar}_{\mathrm{CH}}\right), 125.3\left(\mathrm{Ar}_{\mathrm{CH}}\right), 126.4\left(\mathrm{Ar}_{\mathrm{Cq}}\right), 127.7\left(\mathrm{Ar}_{\mathrm{CH}}\right), 146.2(\mathrm{C}-\mathrm{F}), 146.3(\mathrm{C}-$ $\mathrm{OH}), 176.4(\mathrm{COOH})$; Calculated $[\mathrm{M}]^{+}\left(\mathrm{C}_{9} \mathrm{H}_{10} \mathrm{FNO}_{3}\right) \mathrm{m} / z=199.06$. Found: ESI+: $[\mathrm{M}+\mathrm{H}]^{+} \mathrm{m} / z$ $=200.14$

8d, 2-amino-3-(2-fluoro-5-hydroxyphenyl)propanoic acid; yield: 63\%; beige solid; ${ }^{1} \mathrm{H}$ NMR $\left(D_{2} O\right) \delta(p p m): 3.22$ (ABX syst., $J_{\mathrm{AB}}=14.6 \mathrm{~Hz}, J_{\mathrm{AX}}=7.2 \mathrm{~Hz}, J_{\mathrm{BX}}=5.4 \mathrm{~Hz}, 2 \mathrm{H}, \mathrm{CH}_{2}$ ), 4.42 $(\mathrm{m}, 1 \mathrm{H}, \mathrm{CH}), 6.86(\mathrm{~m}, 2 \mathrm{H}, \mathrm{ArH}), 7.07(\mathrm{~m}, 1 \mathrm{H}, \mathrm{ArH}) ;{ }^{13} \mathrm{C} \mathrm{NMR}\left(\mathrm{D}_{2} \mathrm{O}\right) \delta(p p m): 33.3\left(\mathrm{CH}_{2}\right), 55$ $(\mathrm{CH}), 119.3\left(\mathrm{Ar}_{\mathrm{CH}}\right), 120.7\left(\mathrm{Ar}_{\mathrm{CH}}\right), 124.3\left(\mathrm{Ar}_{\mathrm{CH}}\right), 124.4\left(\mathrm{Ar}_{\mathrm{Cq}}\right), 154.4(\mathrm{C}-\mathrm{OH}), 157.1(\mathrm{C}-\mathrm{F})$, 
$173.5(\mathrm{COOH})$; Calculated $[\mathrm{M}]^{+}\left(\mathrm{C}_{9} \mathrm{H}_{10} \mathrm{FNO}_{3}\right) \mathrm{m} / z=199.06$. Found: ESI+: $[\mathrm{M}+\mathrm{H}]^{+} \mathrm{m} / z=$ 200.04

8e, 2-amino-3-(2,4-dichloro-3-hydroxyphenyl)propanoic acid; yield: 45\%; grey solid; ${ }^{1} \mathrm{H}$ $\operatorname{NMR}\left(D_{2} O\right) \delta(p p m): 3.04-3.45$ (ABX syst., $J_{\mathrm{AB}}=14 \mathrm{~Hz}, J_{\mathrm{AX}}=7 \mathrm{~Hz}, J_{\mathrm{BX}}=4.9 \mathrm{~Hz}, 2 \mathrm{H}$, $\left.\mathrm{CH}_{2}\right)$, 4.7-5.1 (m, 1H, CH), 6.8-6.92 (m, 1H, ArH), 7.10-7.30 (m, 1H, ArH); Calculated [M] ${ }^{+}$ $\left(\mathrm{C}_{9} \mathrm{H}_{9} \mathrm{Cl}_{2} \mathrm{NO}_{3}\right) m / z=249.00$. Found: ESI+: $[\mathrm{M}+\mathrm{H}]^{+} m / z=250.04$

8f, 2-amino-3-(2,6-dichloro-3-hydroxyphenyl)propanoic acid; yield: 10\%; grey solid; ${ }^{1} \mathrm{H}$ $\operatorname{NMR}\left(D_{2} O\right) \delta(p p m): 3.04-3.42$ (ABX syst., $J_{\mathrm{AB}}=14 \mathrm{~Hz}, J_{\mathrm{AX}}=6.9 \mathrm{~Hz}, J_{\mathrm{BX}}=4.9 \mathrm{~Hz}, 2 \mathrm{H}$, $\left.\mathrm{CH}_{2}\right), 5.09-5.12(\mathrm{~m}, 1 \mathrm{H}, \mathrm{CH}), 6.82\left(\mathrm{~d},{ }^{3} J=8.8 \mathrm{~Hz}, 1 \mathrm{H}, \mathrm{ArH}\right), 6.93\left(\mathrm{~d},{ }^{3} J=8.8 \mathrm{~Hz}, 1 \mathrm{H}, \mathrm{ArH}\right)$, ${ }^{13} \mathrm{C}$ NMR $\left(D_{2} \mathrm{O}\right) \delta(p p m): 36.2\left(\mathrm{CH}_{2}\right), 55.9(\mathrm{CH}), 114.7\left(\mathrm{Ar}_{\mathrm{CH}}\right), 121.49\left(\mathrm{Ar}_{\mathrm{CH}}\right), 130.5\left(\mathrm{Ar}_{\mathrm{Cq}}\right)$, $154.4(\mathrm{C}-\mathrm{OH}), 158.0(\mathrm{C}-\mathrm{Cl}), 173.5(\mathrm{COOH})$; Calculated $[\mathrm{M}]^{+}\left(\mathrm{C}_{9} \mathrm{H}_{9} \mathrm{Cl}_{2} \mathrm{NO}_{3}\right) \mathrm{m} / z=249.00$. Found: $\mathrm{ESI}+:[\mathrm{M}+\mathrm{H}]^{+} m / z=250.04$

8g, 2-amino-3-(2,6-difluoro-3-hydroxyphenyl)propanoic acid; yield: 5\%; grey solid; ${ }^{1} \mathrm{H}$ NMR $\left(D_{2} O\right) \delta(p p m): 3.21-3.33$ (ABX syst., $J_{\mathrm{AB}}=14.5 \mathrm{~Hz}, J_{\mathrm{AX}}=7.9 \mathrm{~Hz}, J_{\mathrm{BX}}=5.9 \mathrm{~Hz}, 2 \mathrm{H}, \mathrm{CH}_{2}$ ), 3.93-3.95 (m, 1H, CH), 6.85-7.01 (m, 2H, ArH); Calculated $[\mathrm{M}]^{+}\left(\mathrm{C}_{9} \mathrm{H}_{9} \mathrm{~F}_{2} \mathrm{NO}_{3}\right) \mathrm{m} / z=217.06$. Found: $\mathrm{ESI}+:[\mathrm{M}+\mathrm{H}]^{+} m / z=218.25$

8h, 2-amino-3-[2-fluoro-5-hydroxy-3-(trifluoromethyl)phenyl]propanoic acid; yield: 90\%; white solid; ${ }^{1} \mathrm{H}$ NMR $\left(D_{2} 0\right) \delta(p p m): 3.19-3.42$ (syst. $\mathrm{ABX}, J_{\mathrm{AB}}=14.5 \mathrm{~Hz}, J_{\mathrm{AX}}=7.9 \mathrm{~Hz}, J_{\mathrm{BX}}$ $\left.=5.9 \mathrm{~Hz}, 2 \mathrm{H}, \mathrm{CH}_{2}\right), 4.06-4.09(\mathrm{~m}, 1 \mathrm{H}, \mathrm{CH}), 7.09-7.11(\mathrm{~m}, 1 \mathrm{H}, \mathrm{ArH}), 7.17-7.19(\mathrm{~m}, 1 \mathrm{H}, \mathrm{ArH})$; ${ }^{13} \mathrm{C}$ NMR $\left(D_{2} 0\right) \delta(p p m): 31.5\left(\mathrm{CH}_{2}\right), 55.9(\mathrm{CH}), 119.4\left(\mathrm{Ar}_{\mathrm{CH}}\right), 122.5\left(\mathrm{Ar}_{\mathrm{CH}}\right), 133.6\left(\mathrm{Ar}_{\mathrm{Cq}}\right)$, $155.0(\mathrm{C}-\mathrm{OH}), 149.1\left(\mathrm{C}-\mathrm{CF}_{3}\right), 157.2(\mathrm{C}-\mathrm{F}), 173.5(\mathrm{COOH})$; Calculated $[\mathrm{M}]^{+}\left(\mathrm{C}_{10} \mathrm{H}_{9} \mathrm{~F}_{4} \mathrm{NO}_{3}\right)$ $m / z=267.05$. Found: ESI+: $[\mathrm{M}+\mathrm{H}]^{+} m / z=268.18$

8i, 2-amino-3-(6-chloro-2-fluoro-3-hydroxyphenyl)propanoic acid; yield: 32\%; grey solid; ${ }^{1} \mathrm{H}$ $\operatorname{NMR}\left(D_{2} O\right) \delta(p p m): 2.67-2.73\left(\mathrm{dd},{ }^{3} J=9.5 \mathrm{~Hz},{ }^{4} J=9.45 \mathrm{~Hz}, 1 \mathrm{H}, \mathrm{CH}\right), 3.21-3.25\left(\mathrm{dd},{ }^{4} J=4\right.$ $\left.\mathrm{Hz},{ }^{3} J=12.1 \mathrm{~Hz}, 2 \mathrm{H}, \mathrm{CH}_{2}\right), 6.68-6.72(\mathrm{~m}, 1 \mathrm{H}, \mathrm{ArH}), 6.81-7.01(\mathrm{~m}, 2 \mathrm{H}, \mathrm{ArH}, \mathrm{OH}) ; .{ }^{13} \mathrm{C} \mathrm{NMR}$ $\left(\mathrm{D}_{2} \mathrm{O}\right) \delta(\mathrm{ppm}): 30.55\left(\mathrm{CH}_{2}\right), 54.19(\mathrm{CH}), 116.27\left(\mathrm{Ar}_{\mathrm{CH}}\right), 120.66\left(\mathrm{Ar}_{\mathrm{CH}}\right), 123.70(\mathrm{C}-\mathrm{Cl}), 125.18$ $\left(\mathrm{d},{ }^{2} J_{C-F}=12.6 \mathrm{~Hz}, \mathrm{ArCq}\right), 145.05\left(\mathrm{~d},{ }^{2} J_{C-F}=12.3 \mathrm{~Hz}, \mathrm{C}-\mathrm{OH}\right), 149.25\left(\mathrm{~d},{ }^{1} J_{C-F}=240.7 \mathrm{~Hz}, \mathrm{C}-\right.$ F), $170.08(\mathrm{COOH})$; Calculated $[\mathrm{M}]^{+}\left(\mathrm{C}_{9} \mathrm{H}_{9} \mathrm{ClFNO}_{3}\right) \mathrm{m} / \mathrm{z}=233.03$ Found: ESI+: $[\mathrm{M}+\mathrm{H}]^{+} \mathrm{m} / \mathrm{z}$ $=234.25$ 


\section{Biological activity of compounds 8 a-i}

\section{Filter paper bioassays}

After 4 days of treatment with $m$-tyrosine used at $640 \mu \mathrm{M}$ concentration, the lettuce root length was reduced by about $75 \%$ (Table 2). Adding a chlorine atom in the para position with respect to the hydroxyl group (compound $\mathbf{8 b}$ ) did not affect significantly this inhibition (Table 2). By contrast, addition of a fluorine atom on the same carbon (compounds $\mathbf{8 d}$ and 8g) led to a lack of biological activity of these xenobiotics and further addition of a trifluoromethyl group on the free adjacent position (compound $\mathbf{8 h}$ ) induced a clear increase of root growth under our experimental conditions (Table 2, Fig. 2). This increase was significant at concentrations $\geq 160 \mu \mathrm{M}$ while the root growth inhibition induced by $m$-tyrosine and compound $8 \mathbf{b}$ were clearly significant at concentrations $\geq 40$ and $\geq 80 \mu \mathrm{M}$ respectively (Fig. 2). According to previous filter bioassays, the concentration of $m$-tyrosine required to achieve $50 \%$ reduction of lettuce root growth vary from $10-20 \mu \mathrm{M}$ (Bertin et al. 2009, Bertin et al. 2007) to about $150 \mu \mathrm{M}$ (Kaur et al. 2009). This variability may be due to the fact that $m$-tyrosine is not equally phytotoxic towards the cultivars used or / and to some microbial degradation of this molecule around the seeds when they are not sterilized.

\section{Hydroponic bioassays}

It is well known that $m$-tyrosine microbial degradation is high in soil, the half-life being estimated as less than 24 hours (Kaur et al. 2009). By contrast, in a medium unsuitable for bacterial growth such as ultrapure water, the degradation of $m$-tyrosine as well as compound 8b was extremely low (21 and 17\% respectively after 1.5 months in solution). In the nutritive medium used for lettuce growth, $m$-tyrosine and compound $\mathbf{8 b}$ concentrations remained unchanged during four days then they dropped sharply, especially one week after the beginning of the experiment (Fig. 3). $m$-tyrosine and compound $\mathbf{8 b}$ could not be detected at day 11 and day 14 respectively. If chloramphenicol - a broad spectrum antibiotic - was added at $0.25 \mathrm{~g} . \mathrm{L}^{-1}$ to the medium, the degradation of both compounds was considerably reduced. At day $11, \mathrm{~m}$-tyrosine was detected at $129 \mu \mathrm{M}$ concentration ( $81 \%$ of the initial concentration) and $\mathbf{8 b}$ was detected at $144 \mu \mathrm{M}$ concentration (90\% of the initial concentration). These data indicate that bacterial degradation is slightly less efficient for compound $\mathbf{8 b}$ than for $m$ tyrosine under our experimental conditions. Compound $\mathbf{8 h}$ concentration remained unchanged during the whole experiment (Fig. 3). This does not mean that the latter is not degraded in soil taking into account the diversity and the high content of microorganisms in this compartment. 
Under our experimental conditions, the lettuce root growth was dramatically and similarly inhibited by both $m$-tyrosine and compound $\mathbf{8 b}$ at $40 \mu \mathrm{M}$ (initial concentration) and was reduced by about $65 \%$ in presence of these two compounds at $10 \mu \mathrm{M}$ (initial concentration) (Fig. 4). Our data support those of Bertin et al (2007) (Bertin et al. 2007), which clearly suggest that $m$-tyrosine is a potent inhibitor of plant development. In addition they show that compound 8b, a less soluble (Table 1) and less degradable molecule, can exhibit the same deleterious properties on root development at these two low concentrations. The root growth was not reduced by both $m$-tyrosine and compound $\mathbf{8 b}$ at the lowest concentration used (2.5 $\mu \mathrm{M})$ (Fig. 4). However, it is likely that this initial concentration dropped quickly due to root uptake in addition to microbial degradation, and this may concern all the experiments conducted with higher concentrations. By contrast, in soil, the $m$-tyrosine flux occurs in a dynamic system with exudation from fescue roots on the one hand, microbial degradation, adsorption on soil constituents and receiving plant uptake on the other hand (Duke 2010). The mechanism of $m$-tyrosine uptake by plant tissues is not known but it is possible that a $\mathrm{pH}$ dependent carrier system is involved in addition to diffusion taking into account the low specificity of several amino-acid carrier systems (Chen et al. 2001, Chollet et al. 1997, Deletage-Grandon et al. 2001, Fischer et al. 1995).

Long-term experiments suggest that the deleterious effects induced by high concentrations of $m$-tyrosine and compound $\mathbf{8 b}$ are irreversible. After 14 days of post-germination, the growth of the roots exposed initially to $640 \mu \mathrm{M} m$-tyrosine or compound $\mathbf{8 b}$ remained completely inhibited despite the microbial degradation occurring in the nutritive solution (Fig. 5 A, B and C). The brownish coloration of root tips probably due to oxidation of phenolic compounds by extracellular peroxidases suggests a necrotic state of the apical meristem. Similarly, the shoot development was stopped. Such a herbicidal effect is not necessary in field. In this regard, the dwarf germinations, which are induced by concentrations as low as $10 \mu \mathrm{M}$ (Fig. 4), are not competitive for light and must be dramatically affected by soil drought taking into account the poor development of their root system. The complementary data with compound $\mathbf{8 h}$ from these long-term experiments support and extend those from filter paper bioassays (Table 2, Fig. 2). Treatments with this moderate hydrophilic (Table 1) and stable analogue under our experimental conditions (Fig. 3) led to an increase of primary root growth (Fig. 5D). Furthermore, this response was concomitant with a clear delay of the secondary root emergence and a shoot growth inhibition (Fig. 5, compare A and D). By contrast, $m$-tyrosine promotes lateral root elongation in Arabidopsis and some lettuce isolates (Bertin et al. 2007). 


\section{Conclusion}

Nine halogenated $m$-tyrosine derivatives, among which six are new, have been obtained through a seven-step stereoselective synthesis from commercial halogenated phenol. Filter paper bioassays are an easy method to get preliminary information to evaluate the putative allelochemical properties of these compounds but they need to be completed by more suitable approaches such as hydroponic bioassays. Our experiments support previous data (Bertin et al. 2007). $m$-tyrosine is an efficient allelopathic agent but cannot be used in field because of its high microbial degradation (Bertin et al. 2009, Kaur et al. 2009). Our data indicate that it is possible, by halogen addition, to manipulate: $i$ / the biological properties of $m$-tyrosine, from similar (compound $\mathbf{8 b}$ ) to contrary (compound $\mathbf{8 h}$ ) properties on root growth, ii/ the stability of these compounds in non-sterilized conditions. Compound $\mathbf{8 b}$ is slightly less degraded than $m$-tyrosine while compound $\mathbf{8 h}$ remained stable for at least two weeks under our experimental conditions. Finally, these two halogenated derivatives, which induced deleterious but contrary effects on seedling development, may be tools to elucidate the mechanisms of the biological activity of $m$-tyrosine. Our investigation is a complementary approach to opposite strategies consisting to confer resistance to exogenously added m-tyrosine (Huang et al. 2010). 


\section{References}

Bais HP, Weir TL, Perry LG, Gilroy S, Vivanco JM (2006) The role of root exudates in rhizosphere interations with plants and other organisms. Annu. Rev. Plant Biol. 57: 233-266

Bertin C, Weston LA (2002) Fescue ecology, physiology, and allelopathy - A case study. In: Reigosa MJ, Pedrol N (Editors), Allelopathy: From Molecules to Ecosystems, Science Publisher, Inc., New Hampshire, USA, pp. 93-112

Bertin C, Weston LA, Huang T, Jander G, Owens T, Meinwald J, Schroeder FC (2007) Grass roots chemistry: meta-tyrosine, an herbicidal nonprotein amino acid. Proc. Natl. Acad. Sci. USA 104: 16964-9

Bertin C, Harmon R, Akaogi M, Weidenhamer JD, Weston LA (2009) Assessment of the Phytotoxic Potential of m-Tyrosine in Laboratory Soil Bioassays. J. Chem. Ecol. 35: 1288-1294

Birkett MA, Chamberlain K, Hooper AM, Pickett JA (2001) Does allelopathy offer real promise for practical weed management and for explaining rhizosphere interactions involving higher plants? Plant Soil 232: 31-39

Bovonsombat P, Khanthapura P, Krause MM, Leykajarakul J (2008) Facile syntheses of 3halo and mixed 3,5-dihalo analogues of $\mathrm{N}$-acetyl-L-tyrosine via sulfonic acidcatalysed regioselective monohalogenation. Tetrahedron Lett. 49: 7008-7011

Caro JH (1969) Accumulation by plants of organochlorine insecticides from soil. Phytopathology 59: 1191-1197

Chen L, Ortiz-Lopez A, Jung A, Bush DR (2001) ANT1, an aromatic and neutral amino acid transporter in Arabidopsis. Plant Physiol. 125: 1813-20

Chollet JF, Deletage C, Faucher M, Miginiac L, Bonnemain JL (1997) Synthesis and structure-activity relationships of some pesticides with an alpha-amino acid function. Biochim. Biophys. Acta 1336: 331-41

Chou CH (2006) Introduction to allelopathy. In: Reigosa MJ, Pedrol N, González L (Editors), Allelopathy: a physiological process with ecological implications, Springer, Dordrecht, pp. 1-9

Clark RD (2012) A perspective on the role of quantitative structure-activity and structureproperty relationships in herbicide discovery. Pest Manage. Sci. 68: 513-8

Dayan FE, Owens DK, Duke SO (2012) Rationale for a natural products approach to herbicide discovery. Pest Manage. Sci. 68: 519-28

Deletage-Grandon C, Chollet JF, Faucher M, Rocher F, Komor E, Bonnemain JL (2001) Carrier-mediated uptake and phloem systemy of a 350-Dalton chlorinated xenobiotic with an alpha-amino acid function. Plant Physiol. 125: 1620-32

Drain DJ, Howes JGB (1967), Phenylalanine derivatives and their preparation. GB1068937. 
Duke SO, Lydon J (1993) Natural phytotoxins as herbicides. In: Duke SO, Menn JJ, Plimmer JR (Editors), Pest Control with Enhanced Environmental Safety. ACS Symposium Series, vol. 524, American Chemical Society, Washington, pp. 110-124

Duke SO, Abbas HK (1995) Natural-products with potential use as herbicides. In: Inderjit A, Dakshini KMM, Einhellig FA (Editors), Allelopathy - Organisms, Processes, and Applications. ACS Symposium Series, vol. 582, American Chemical Society, Washington, pp. 348-362

Duke SO, Dayan EE, Kagan IA, Baerson SR (2005) New herbicide target sites from natural compounds. In: Clark JM, Ohkawa H (Editors), New Discoveries in Agrochemicals. ACS Symposium Series, vol. 892, American Chemical Society, Washington, pp. 151160

Duke SO (2010) Allelopathy: Current status of research and future of the discipline: A Commentary. Allelopathy Journal 25: 17-29

Duke SO (2012) Why have no new herbicide modes of action appeared in recent years? Pest Manage. Sci. 68: 505-12

Epstein L, Bassein S (2003) Patterns of pesticide use in California and the implications for strategies for reduction of pesticides. Annu. Rev. Phytopathol. 41: 351-375

Farooq M, Jabran K, Cheema ZA, Wahid A, Siddique KHM (2011) The role of allelopathy in agricultural pest management. Pest Manage. Sci. 67: 493-506

Felding G (1992a) Leaching of atrazine into ground-water. Pestic. Sci. 35: 39-43

Felding G (1992b) Leaching of atrazine and hexazinone from Abies-nordmanniana (steven) spach plantations. Pestic. Sci. 35: 271-275

Fischer WN, Kwart M, Hummel S, Frommer WB (1995) Substrate specificity and expression profile of amino acid transporters (AAPs) in Arabidopsis. J. Biol. Chem. 270: 1631520

Gosme M, Suffert F, Jeuffroy MH (2010) Intensive versus low-input cropping systems: What is the optimal partitioning of agricultural area in order to reduce pesticide use while maintaining productivity? Agricultural Systems 103: 110-116

Hall JK, Mumma RO, Watts DW (1991) Leaching and runoff losses of herbicides in a tilled and untilled field. Agric., Ecosyst. Environ. 37: 303-314

Huang TF, Tohge T, Lytovchenko A, Fernie AR, Jander G (2010) Pleiotropic physiological consequences of feedback-insensitive phenylalanine biosynthesis in Arabidopsis thaliana. Plant J. 63: 823-835

Huang TF, Rehak L, Jander G (2012) meta-Tyrosine in Festuca rubra ssp commutata (Chewings fescue) is synthesized by hydroxylation of phenylalanine. Phytochemistry 75: $60-66$

Jacobsen BJ (1997) Role of plant pathology in integrated pest management. Annu. Rev. Phytopathol. 35: 373-391 
John J, Shirmila J, Sarada S, Anu S (2010) Role of Allelopathy in vegetables crops production. Allelopathy Journal 25: 275-311

Karabelas AJ, Plakas KV, Solomou ES, Drossou V, Sarigiannis DA (2009) Impact of European legislation on marketed pesticides - A view from the standpoint of health impact assessment studies. Environ. Int. 35: 1096-1107

Kaur H, Kaur R, Kaur S, Baldwin IT, Inderjit (2009) Taking ecological function seriously: soil microbial communities can obviate allelopathic effects of released metabolites. PLoS One 4: e4700

Kirk KL, Olubajo O, Buchhold K, Lewandowski GA, Gusovsky F, McCulloh D, Daly JW, Creveling CR (1986) Synthesis and adrenergic activity of ring-fluorinated phenylephrines. J. Med. Chem. 29: 1982-1988

Konkel JT, Fan JF, Jayachandran B, Kirk KL (2002) Syntheses of 6-fluoro-meta-tyrosine and of its metabolites. J. Fluorine Chem. 115: 27-32

Li ZH, Wang QA, Ruan XA, Pan CD, Jiang DA (2010) Phenolics and Plant Allelopathy. Molecules 15: 8933-8952

Macias FA (1995) Allelopathy in the search for natural herbicide models. In: Inderjit A, Dakshini KMM, Einhellig FA (Editors), Allelopathy - Organisms, Processes, and Applications. ACS Symposium Series, vol. 582, pp. 310-329

Molisch H (1937) Der Einfluss einer Pflanze auf die andere-Allelopathie. Gustav Fischer, Jena, $106 \mathrm{pp}$

Mueller JF, Harden F, Toms LM, Symons R, Furst P (2008) Persistent organochlorine pesticides in human milk samples from Australia. Chemosphere 70: 712-720

Niemeyer HM (2009) Hydroxamic acids derived from 2-hydroxy-2H-1,4-benzoxazin-3(4H)one: key defense chemicals of cereals. J. Agric. Food. Chem. 57: 1677-96

Ntow WJ, Tagoe LM, Drechsel P, Kelderman P, Gijzen FJ, Nyarko E (2008) Accumulation of persistent organochlorine contaminants in milk and serum of farmers from Ghana. Environ. Res. 106: 17-26

Petroski RJ, Stanley DW (2009) Natural compounds for pest and weed control. J. Agric. Food. Chem. 57: 8171-9

Rabbinge R, vanOijen M (1997) Scenario studies for future agriculture and crop protection. Eur. J. Plant Pathol. 103: 197-201

Rice EL (1984) Allelopathy. Academic Press, Orlando, 422 pp

Smith AG, Gangolli SD (2002) Organochlorine chemicals in seafood: occurrence and health concerns. Food Chem. Toxicol. 40: 767-779

Tesio F, Ferrero A (2010) Allelopathy, a chance for sustainable weed management. International Journal of Sustainable Development and World Ecology 17: 377-389 
van Lenteren JC (2000) A greenhouse without pesticides: fact or fantasy? Crop Protect. 19: 375-384

VanBrocklin HF, Blagoev M, Hoepping A, O'Neil JP, Klose M, Schubiger PA, Ametamey S (2004) A new precursor for the preparation of 6-[18F]Fluoro-L-m-tyrosine ([18F]FMT): efficient synthesis and comparison of radiolabeling. Appl. Radiat. Isot. 61: 1289-94

Vasdev N, Chirakal R, Schrobilgen GJ, Nahmias C (2001) Selectivity of elemental fluorine towards L-tyrosine and L-alpha-methyltyrosine in acidic media and the syntheses of their F-18 3-fluoro and F-18 3,5-difluoro derivatives. J. Fluorine Chem. 111: 17-25

Vyvyan JR (2002) Allelochemicals as leads for new herbicides and agrochemicals. Tetrahedron 58: 1631-1646

Weston LA, Bertin C, Schroeder F (2006), A bioherbicide from festuca spp. WO2006086474.

Whittaker RH, Feeny PP (1971) Allelochemics: chemical interactions between species. Science 171: 757-70

Wu H, Haig T, Pratley J, Lemerle D, An M (2001) Allelochemicals in wheat (Triticum aestivum L.): cultivar difference in the exudation of phenolic acids. J. Agric. Food. Chem. 49: 3742-5

Zadoks JC (1991) A hundred and more years of plant-protection in the Netherlands. Netherlands J. Plant Pathol. 97: 3-24

\section{Figure legends}

Fig. 1 General reaction scheme

Fig. 2 Effect of m-Tyr, $\mathbf{8 b}$ and $\mathbf{8 h}$ at various concentrations on lettuce (L. sativa var Bonde Parisienne) seedling root growth (filter paper bioassays). Radicle and shoot length were measured 4 days after sowing. The KruskalWallis test was used to assess statistically significant differences in comparison to control. (*** $\mathrm{P}<0.001 ; * * \mathrm{P}$ $<0.01$; NS, not significant). For box plots, $\mathrm{n}=20$

Fig. 3 Time-course changes over an-18-day period of m-Tyr, $\mathbf{8 b}$ and $\mathbf{8 h}$ concentrations in the nutrient solution used for lettuce growth. The initial concentration of the products was $160 \mu \mathrm{M}$. Dark conditions, temperature 20 $\pm 1^{\circ} \mathrm{C}$. Mean of 3 assays

Fig. 4 Effect of m-Tyr and $\mathbf{8 b}$ at various concentrations on lettuce (L. sativa var Bonde Parisienne) seedling root growth (hydroponic experiments). Radicle and shoot length were measured 6 days after sowing. The KruskalWallis test was used to assess statistically significant differences in comparison to control. (*** $\mathrm{P}<0.001$; NS, not significant). For box plots, $n=25$ for control and $n=9$ for the other experiments

Fig. 5 Long-term effect (14 days) of $m$-tyrosine (B), $\mathbf{8 b}$ (C) and $\mathbf{8 h}$ (D) used at $640 \mu \mathrm{M}$ concentration on lettuce seedling growth. Seedlings were grown under dim daylight conditions in a controlled environment $\left(21 \pm 0.5^{\circ} \mathrm{C}\right.$, HR $90 \pm 5 \%$ ) for the first week after sowing and then at $24 \pm 0.5^{\circ} \mathrm{C}$ and $60 \% \mathrm{RH}$ during the photoperiod $(14 \mathrm{~h}$, $250 \mu \mathrm{mol}$ photons. $\left.\mathrm{m}^{-2} \cdot \mathrm{s}^{-1}\right)$. Two arrows localize each Pasteur pipette. A: control 


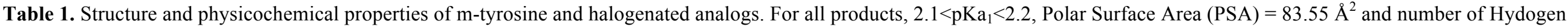

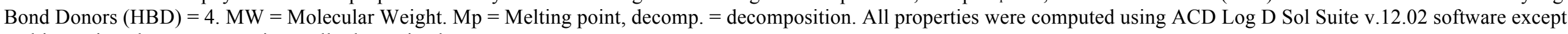
melting points that were experimentally determined.

\begin{tabular}{|c|c|c|c|c|c|c|c|c|c|c|}
\hline \multirow{2}{*}{ Product } & \multirow{2}{*}{ Structure } & \multirow{2}{*}{ MW } & \multirow{2}{*}{$\mathrm{Mp}\left({ }^{\circ} \mathrm{C}\right)$} & \multirow{2}{*}{$\begin{array}{c}\text { Halogen } \\
\text { ratio }\end{array}$} & \multicolumn{3}{|c|}{$\log D$} & \multicolumn{3}{|c|}{ Water solubility (mg.ml $\left.{ }^{-1}\right)$} \\
\hline & & & & & pH 4.0 & $\mathrm{pH} 6.0$ & pH 8.0 & $\mathrm{pH} 4.0$ & pH 6.0 & pH 8.0 \\
\hline m-Tyr & & 181.19 & $\begin{array}{l}275-281 \\
\text { decomp. }\end{array}$ & 0.00 & -2.95 & -2.94 & -2.97 & 10.65 & 10.5 & 11.35 \\
\hline $8 a$ & & 215.63 & $\begin{array}{l}\text { 273-277 } \\
\text { decomp. }\end{array}$ & 0.07 & -2.16 & -2.16 & -2.33 & 1.21 & 1.2 & 1.86 \\
\hline $8 b$ & & 215.63 & $\begin{array}{l}249-251 \\
\text { decomp. }\end{array}$ & 0.07 & -1.96 & -1.96 & -2.02 & 1.08 & 1.07 & 1.25 \\
\hline $8 c$ & & 199.18 & $235-239$ & 0.07 & -2.76 & -2.76 & -2.88 & 31.19 & 30.89 & 42.31 \\
\hline $8 d$ & & 199.18 & $\begin{array}{l}271-278 \\
\text { decomp. }\end{array}$ & 0.07 & -2.75 & -2.74 & -2.79 & 30.39 & 30.03 & 33.82 \\
\hline $8 e$ & & 250.08 & $\begin{array}{l}\text { 221-239 } \\
\text { decomp. }\end{array}$ & 0.13 & -1.56 & -1.6 & -2.38 & 0.15 & 0.17 & 2.15 \\
\hline $8 f$ & & 250.08 & $\begin{array}{r}90-130 \\
\text { decomp. }\end{array}$ & 0.13 & -1.18 & -1.18 & -1.51 & 0.12 & 0.12 & 0.29 \\
\hline $8 g$ & & 217.17 & $\begin{array}{l}\text { 238-241 } \\
\text { decomp. }\end{array}$ & 0.13 & -2.61 & -2.61 & -2.76 & 27.07 & 26.88 & 39.09 \\
\hline $8 h$ & & 267.18 & $\begin{array}{l}248-255 \\
\text { decomp. }\end{array}$ & 0.22 & -0.97 & -0.97 & -1.09 & 2.75 & 2.73 & 3.65 \\
\hline $8 i$ & & 233.62 & $\begin{array}{l}264-271 \\
\text { decomp. }\end{array}$ & 0.13 & -1.76 & -1.76 & -2.02 & 7.92 & 7.91 & 15.5 \\
\hline
\end{tabular}


Table 2. Short time effect of halogenated products at $640 \mu \mathrm{M}$ concentration on lettuce root elongation in filter paper bioassays. For each experiment (A-F), one or two halogenated compounds were tested simultaneously with m-Tyr and control (without any product). Root length of seedlings was measured 4 days after placing seeds in control, m-tyrosine and m-tyrosine derivatives treatments. Results are expressed as the percentage of root growth inhibition in comparison to the control of the same experiment ( $A, B, C, D, E$ or $F)$, taking into account the median of the main root length of 20 seedlings. The Kruskal-Wallis test was used to assess statistically significant differences in comparison to control $\left({ }^{* * *} p<0.001,{ }^{* *} p<0.01,{ }^{*} p<0.05\right.$, (NS) non significant).

\begin{tabular}{ccc} 
Product & Experiment & Inhibition of root growth (\%) \\
\hline $\mathrm{m}-\mathrm{Tyr}$ & $\mathrm{D}$ & $76.7^{* * *}$ \\
$\mathbf{8 a}$ & & $34.9^{* *}$ \\
\hline $\mathrm{m}-\mathrm{Tyr}$ & $\mathrm{A}$ & $82.9^{* * *}$ \\
$\mathbf{8 b}$ & & $75.6^{* * *}$ \\
$\mathrm{~m}-\mathrm{Tyr}$ & $\mathrm{F}$ & $78.3^{* * *}$ \\
$\mathbf{8 b}$ & & $65.2^{* * *}$ \\
\hline $\mathrm{m}-\mathrm{Tyr}$ & $\mathrm{A}$ & $82.9^{* * *}$ \\
$\mathbf{8 c}$ & & $61.0^{* * *}$ \\
\hline $\mathrm{m}-\mathrm{Tyr}$ & $\mathrm{D}$ & $76.7^{* * *}$ \\
$\mathbf{8 d}$ & & $2.3(\mathrm{NS})$ \\
\hline $\mathrm{m}-\mathrm{Tyr}$ & $\mathrm{C}$ & $75.8^{* * *}$ \\
$\mathbf{8 e}$ & & $33.3^{*}$ \\
\hline $\mathrm{m}-\mathrm{Tyr}$ & $\mathrm{E}$ & $70.5^{* * *}$ \\
$\mathbf{8 f}$ & & $53.8^{* * *}$ \\
\hline $\mathrm{m}-\mathrm{Tyr}$ & $\mathrm{B}$ & $90.7^{* * *}$ \\
$\mathbf{8 g}$ & & $7.0(\mathrm{NS})$ \\
\hline $\mathrm{m}-\mathrm{Tyr}$ & $\mathrm{C}$ & $75.8^{* * *}$ \\
$\mathbf{8 h}$ & & $-51.5^{* *}$ \\
$\mathrm{~m}-\mathrm{Tyr}$ & $\mathrm{F}$ & $78.3^{* * *}$ \\
$\mathbf{8 h}$ & & $-58.7^{* * *}$ \\
\hline $\mathrm{m}-\mathrm{Tyr}$ & $\mathrm{E}$ & $70.5^{* * *}$ \\
$\mathbf{8 i}$ & & $48.7^{* * *}$ \\
\hline
\end{tabular}


<smiles>[R]c1cc([R])c([125I])c([R3])c1O</smiles>

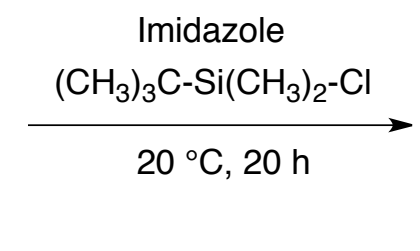<smiles>[R]c1cc([R])c(O[Si](C)(C)C(C)(C)C)c([R3])c1[R]</smiles>

a) sec-Butyllithium $-78{ }^{\circ} \mathrm{C}, 1 \mathrm{~h}$

b) Dimethylformamide, $-78^{\circ} \mathrm{C}, 30 \mathrm{~min}$

c) Tetra-n-butylammonium fluoride, $-78^{\circ} \mathrm{C}, 30 \mathrm{~min}$<smiles>[R]c1c([R3])c(C=O)c([R])c(OCc2ccccc2)c1[R]</smiles><smiles>[R]c1c([R])c(O)c([R])c(C=O)c1[R]</smiles>

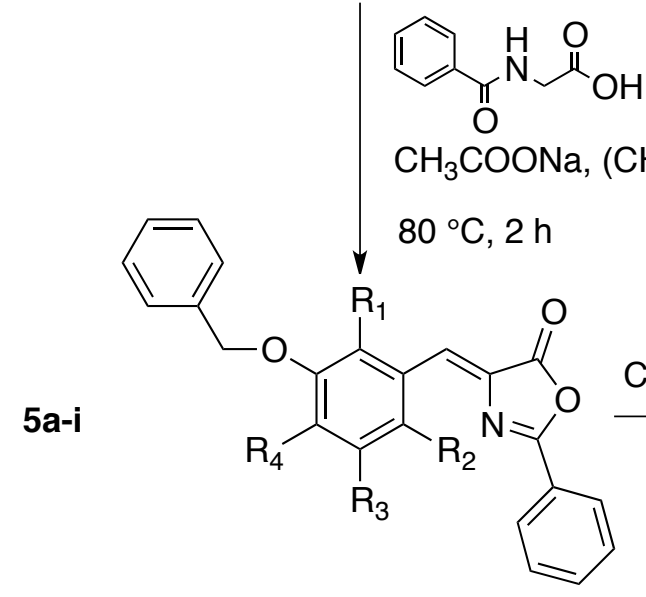<smiles>[R]c1c([R5])c(/C=C(\NC(=O)c2ccccc2)C(=O)OC)c([R8])c(OCc2ccccc2)c1[R]</smiles>
$6 a-i$

8a-i

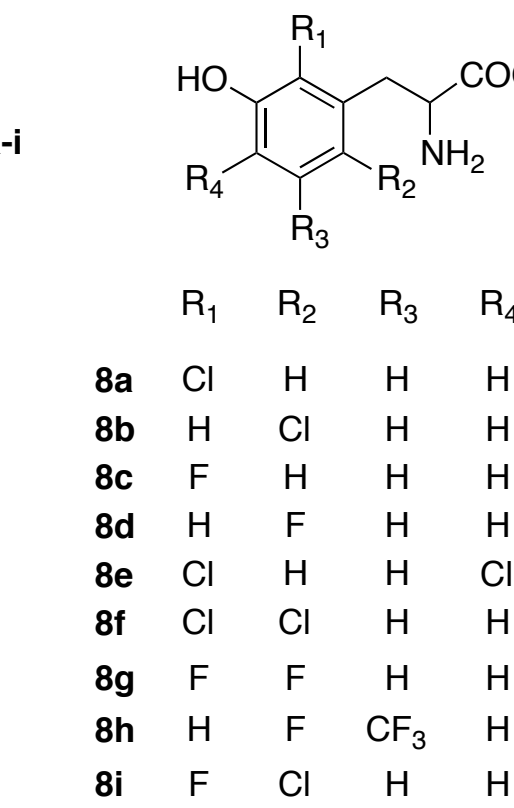

Figure 1: General reaction scheme 


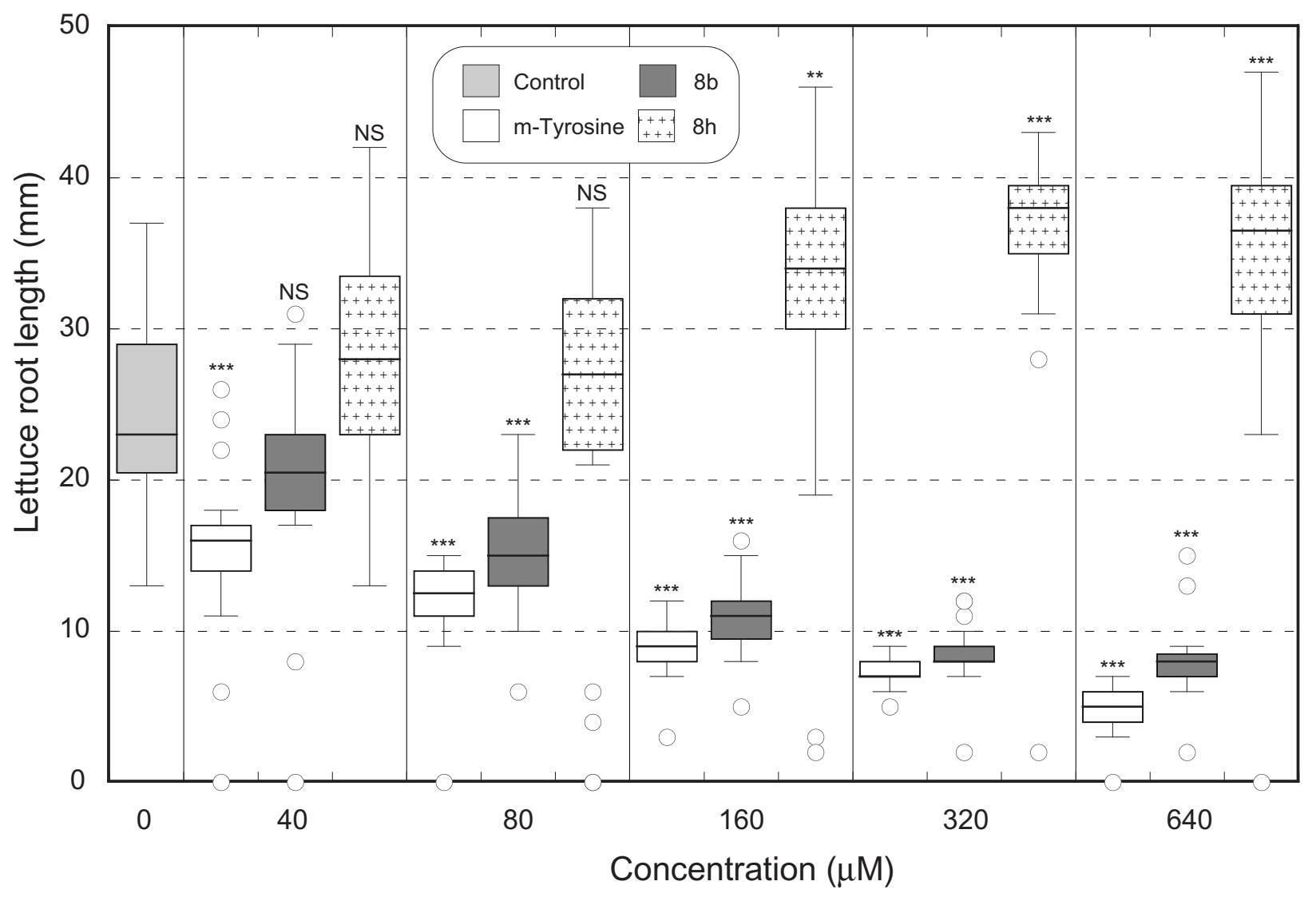

Figure 2: Effect of $\mathrm{m}-\mathrm{Tyr}, \mathbf{8 b}$ and $\mathbf{8} \mathbf{h}$ at various concentrations on lettuce (L. sativa var Bonde Parisienne) seedling root growth (filter paper biossays).

Radicle and shoot length were measured 4 days after sowing.The Kruskal-Wallis test was used to assess statistically significant differences in comparison to control. $\left({ }^{* * *} \mathrm{P}<0.001 ;{ }^{* *} \mathrm{P}<0.01\right.$; NS, not significant). For box plots, $\mathrm{n}=20$. 


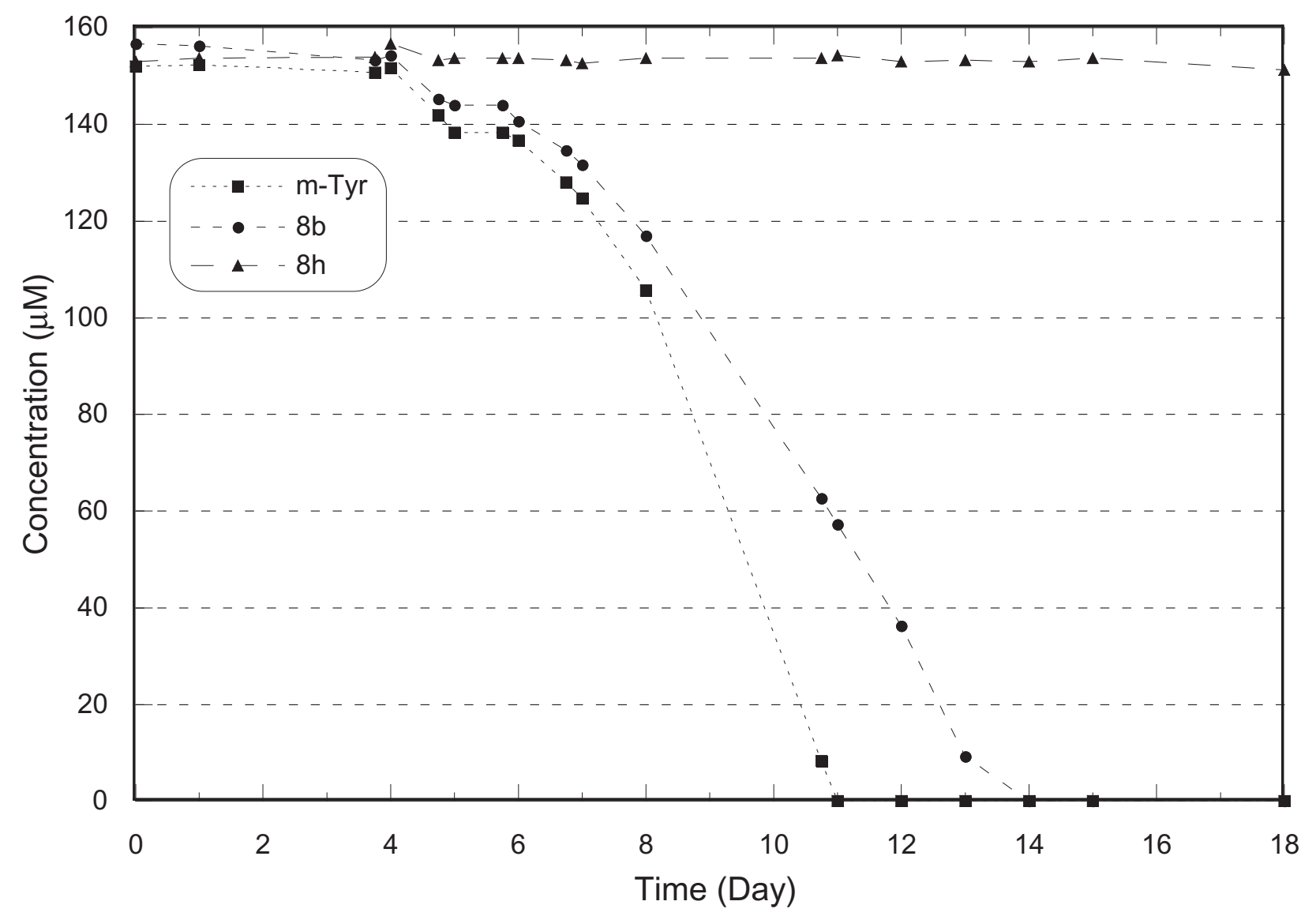

Figure 3 : Time-course changes over a 18 day-period of $\mathrm{m}$-Tyr, $\mathbf{8 b}$ and $\mathbf{8 h}$ concentrations in the nutrient solution used for lettuce growth. The initial concentration of the products was $160 \mu \mathrm{M}$. Dark conditions, temperature $20 \pm 1^{\circ} \mathrm{C}$. Mean of 3 assays. 


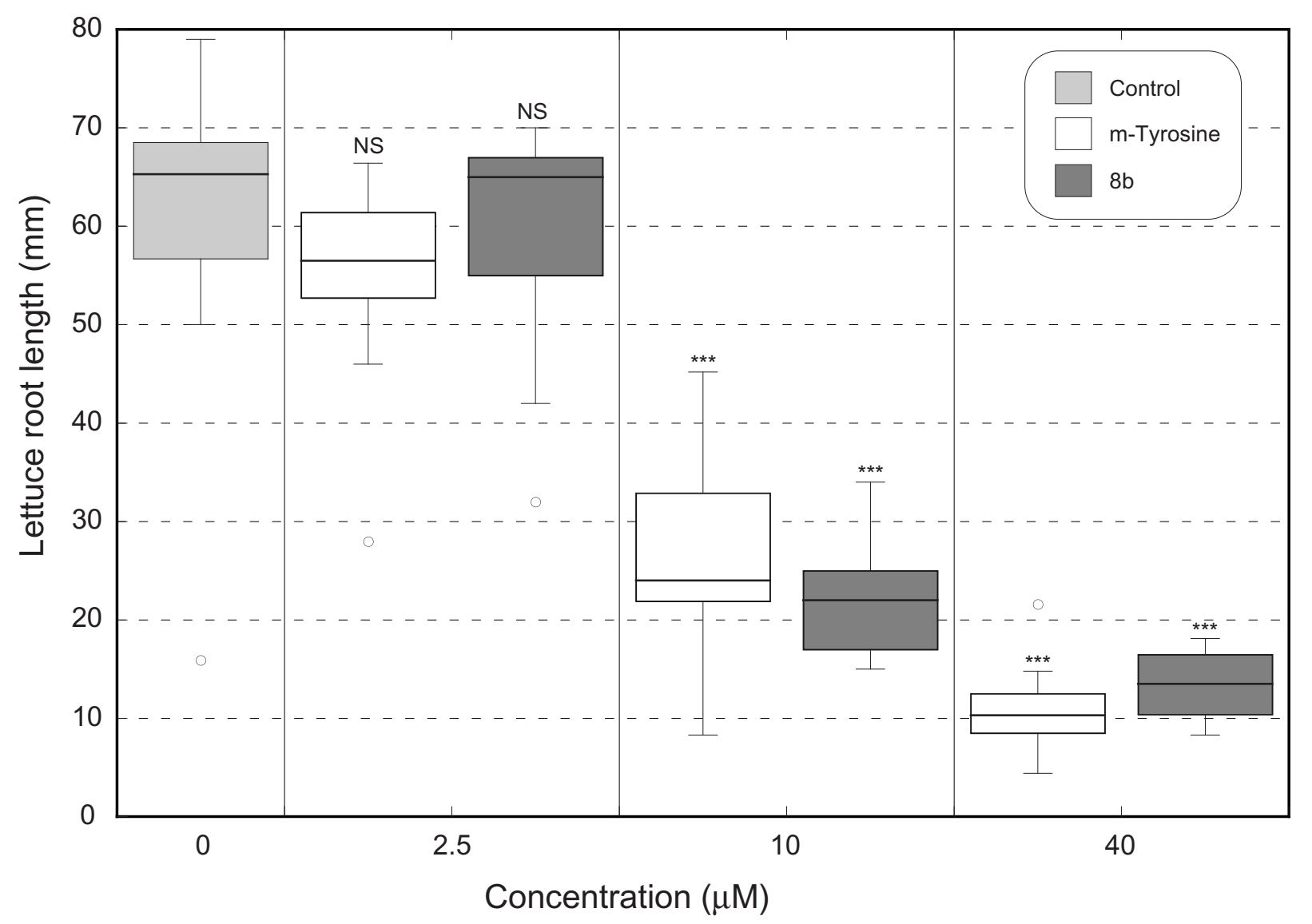

Figure 4: Effect of $m-T y r$ and $\mathbf{8 b}$ at various concentrations on lettuce (L. sativa var Bonde Parisienne) seedling root growth (hydroponic experiments). Radicle and shoot length were measured 6 days after sowing.The Kruskal-Wallis test was used to assess statistically significant differences in comparison to control. (*** $\mathrm{P}<0.001 ; \mathrm{NS}$, not significant).

For box plots, $n=25$ for control and $n=9$ for the other experiments. 

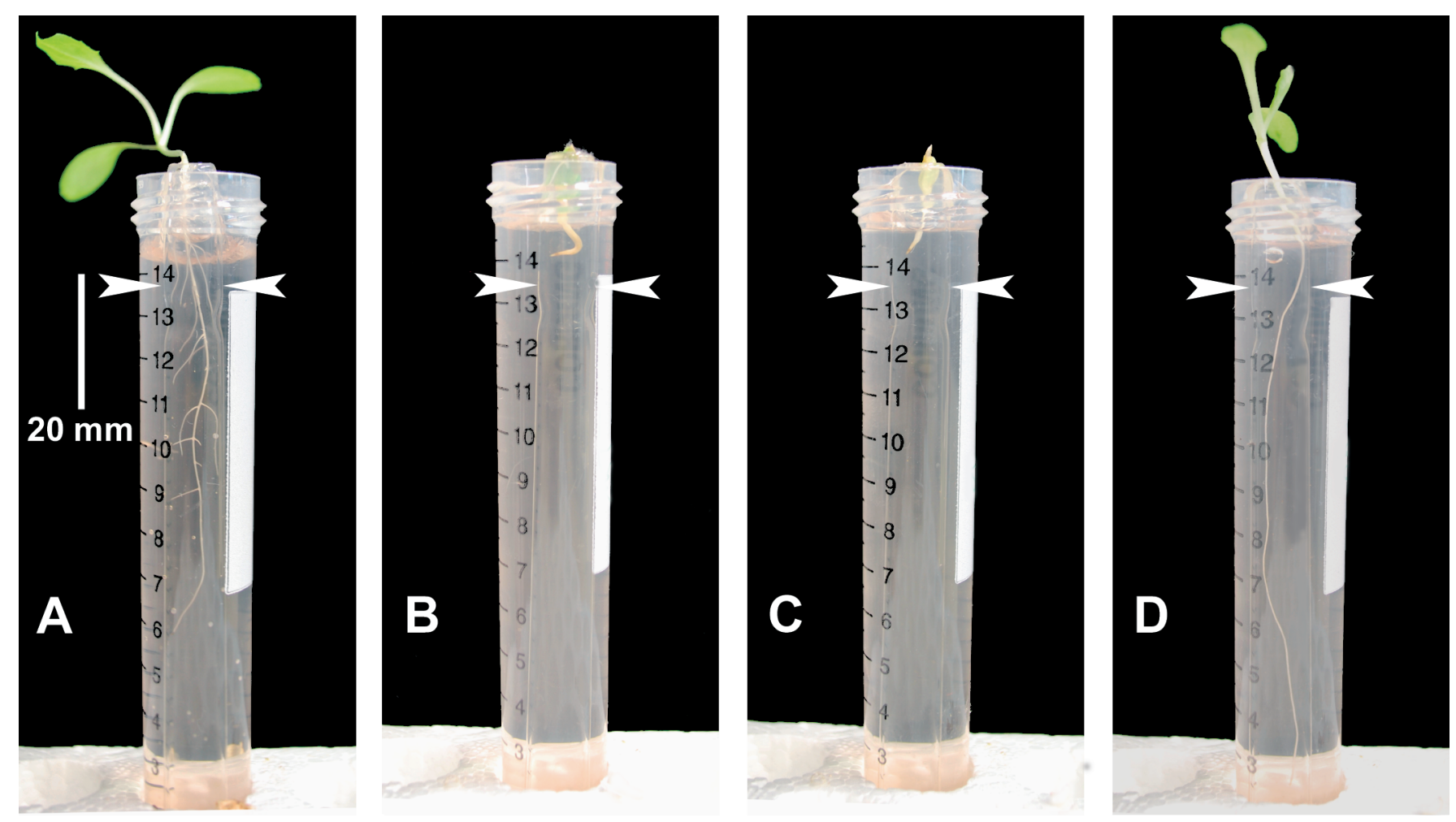

Figure 5: Long-term effect (14 days) of $\mathrm{m}$-Tyrosine (B), $8 \mathbf{b}(\mathrm{C})$ and $8 \mathrm{~h}(\mathrm{D})$ used at $640 \mu \mathrm{M}$ concentration on lettuce seedling growth. Seedlings were grown under dim daylight conditions in a controlled environment $\left(21 \pm 0.5^{\circ} \mathrm{C}, \mathrm{HR} 90 \pm 5 \%\right)$ for the first week after sowing and then at $24 \pm 0.5^{\circ} \mathrm{C}$ and $60 \% \mathrm{RH}$ during the photoperiod ( $14 \mathrm{~h}, 250 \mu \mathrm{mol}$ photons. $\left.\mathrm{m}^{-2} \cdot \mathrm{s}^{-1}\right)$. Two arrows localize each Pasteur pipette. A: control. 